Journal of Technology and Social for Community Service (JTSCS)

Vol. 2, No. 2, September 2021, page-page. 37 42

P-ISSN: 2723-455X

E-ISSN: 2723-2026

available online at: https://ejurnal.teknokrat.ac.id/index.php/teknoabdimas

\title{
Maksimalisasi Media Sosial untuk Meningkatkan Pendapatan dan Pengembangan Diri Generasi $Z$ di MAN 1 Pesawaran
}

\author{
Lia Febria Lina ${ }^{1}$, Almira Devita Putri ${ }^{2}$, Defia Riski Anggarini ${ }^{3}$ \\ Universitas Teknokrat Indonesia ${ }^{1,2,3}$
}

Email : Liafebrialina@teknokrat.ac.id ${ }^{1}$, Almiradevita@teknokrat.ac.id ${ }^{2}, \underline{\text { Defiariski@teknokrat.ac.id }}$

\begin{tabular}{lll}
\hline Received: (24 Juni 2021) & Accepted: (30 Agustus 2021) & Published : (15 September 2021) \\
\hline
\end{tabular}

\begin{abstract}
In the era of the Internet of Things, people cannot be separated from the internet in carrying out their activities, especially Generation $Z$ which is considered as iGeneration or the internet generation or net generation. Generation $Z$ who became the sample of this community service were 35 students of MAN 1 Pesawaran. The purpose of this community service is to give an understanding to Generation $Z$ to be able to utilize and maximize social media to develop themselves and earn the income. As a result of this activity, students have gained an increased understanding of the use of social media for personal growth and increased revenue.
\end{abstract}

Keywords: Social Media, Gen Z, Personal Growth.

\begin{abstract}
Abstrak
Pada era Internet of Things, membuat masyarakat tidak bisa lepas dengan internet dalam menjalankan aktivitasnya, khususnya Generasi Z yang diaggap sebagai iGeneration atau generasi internet atau generasi net. Generasi $Z$ yang menjadi sampel dari pengabdian masyarakat ini adalah siswa/siswi MAN 1 Pesawaran sebanyak 35 siswa/siswi. Tujuan pengabdian masyarakat ini untuk memberikan pemahaman kepada Generasi $\mathrm{Z}$ untuk dapat memanfaatkan dan memaksimalkan media sosial untuk pengembangan diri dan mendapatkan pendapatan. Hasil dari kegiatan ini, siswa atau siswi telah mendapatkan peningkatan pemahaman mengenai pemanfaatan media sosial baik untuk pengembangan diri maupun peningkatan pendapatan
\end{abstract}

Kata Kunci: Media Sosial, Generasi Z, Pengembangan Diri.

\section{To cite this article:}

Lia Febria Lina, Almira Devita Putri, Defia Riski Anggarini. (2021). Maksimalisasi Media Sosial untuk Meningkatkan Pendapatan dan Pengembangan Diri Generasi Z di MAN 1 Pesawaran. Journal of Technology and Social for Community Service (JTSCS), Vol(2), 37-42.

\section{PENDAHULUAN}

Pada era Internet of Things, membuat masyarakat tidak bisa lepas dengan internet dalam menjalankan aktivitasnya. Hal ini juga mempengaruhi cara komunikasi konsumen yang lebih banyak menghabiskan komunikasi lewat komentar dan saling mengirim pesan di media sosial (Lina dan Permatasari, 2019). Menurut Kominfo (2017) terdapat 132 juta pengguna internet yang aktif atau sekitar 52\% dari jumlah penduduk yang ada, terdapat 129 juta yang memiliki akun media sosial yang aktif dan rata-rata menghabiskan waktu 3,5 jam per hari untuk konsumsi internet melalui handphone. Generasi Z atau Gen Z disebut sebagai generasi yang lahir setelah generasi Y. Kumpulan orang yang termasuk ke dalam generasi ini adalah mereka yang lahir di tahun 1995 sampai dengan 2010. Generasi Z disebut juga sebagai iGeneration atau generasi internet atau generasi net. Mereka selalu terhubung dengan dunia maya dan dapat melakukan segala sesuatunya dengan menggunakan kecanggihan teknologi yang ada. Siswa/siswi MAN 1 Pesawaran termasuk dalam Generasi Z. Berdasarkan wawancara singkat dengan siswa-siswi MAN 1 Pesawaran mereka bahkan dapat menghabiskan waktu di media sosial selama 4-6 jam untuk mencari hiburan dan informasi. Kominfo (2017) menyatakan bahwa media sosial 
juga dapat memberikan pengaruh negatif bagi masyarakat seperti informasi yang meresahkan, yang mengadu domba, ujaran-ujaran kebencian, pernyataan-pernyataan yang kasar, pernyataan-pernyataan yang mengandung fitnah, yang provokatif.

Berdasarkan beberapa data yang diperoleh, generasi $\mathrm{Z}$ memiliki peluang besar dan juga kendala. Salah satu peluang yang menjadi kekuatan generasi $Z$ adalah mereka lahir di era internet dimana dapat pemanfaatan internet dan media sosial lebih familiar. Kelebihan ini dapat dimanfaatkan oleh generasi $\mathrm{Z}$ untuk memulai bisnis dengan memanfaatkan internet dan media sosial. Namun, jika tidak diarahkan dengan baik, media sosial juga dapat memberikan pengaruh yang negatif bagi seseorang. Generasi $Z$ yang sangat rentan dengan paparan internet ini perlu diberikan pemahaman untuk dapat memanfaatkan hal positif yang ada dan menghindari hal-hal negatif tersebut. Bukan hanya itu, pemasaran media sosial diartikan sebagai pemasaran yang dilakukan dengan menggunakan media sosial untuk mencapai organisasi dengan menciptakan nilai bagi pemangku kepentingan (Felix et al., 2016). Sehingga sangat penting bagi generasi $Z$ untuk mendapatkan pemahaman tersebut. Tujuan pengabdian masyarakat ini adalah untuk meberikan pemahaman Generasi $Z$ tentang pengaruh positif dan negatif media sosial, membeberikan pemahaman media sosial untuk membantu mengembangkan diri yang terakhir adalah memberikan pemahaman bahwa terdapat fitur di media sosial yang dapat dimanfaatkan untuk mendapatkan penghasilan. Sehingga judul yang diangkat dalam pengabdian ini ialah "Maksimalisasi media sosial untuk meningkatkan pendapatan generasi Z di MAN 1 Pesawaran)".

\section{METODE PELAKSANAAN}

\section{Tempat dan Waktu:}

Tempat : MAN 1 Pesawaran

Waktu : : Selasa, 25 Mei 2021 dan Rabu, 16 Juni 2021

Pelaksanaan kegiatan ini menggunakan 3 metode untuk dapat mencapai tujuan yaitu:

1. Ceramah, dimana pemateri menjelaskan bagaimana memaksimalkan media sosial untuk pengembangan diri dan mendapatkan pendapatan

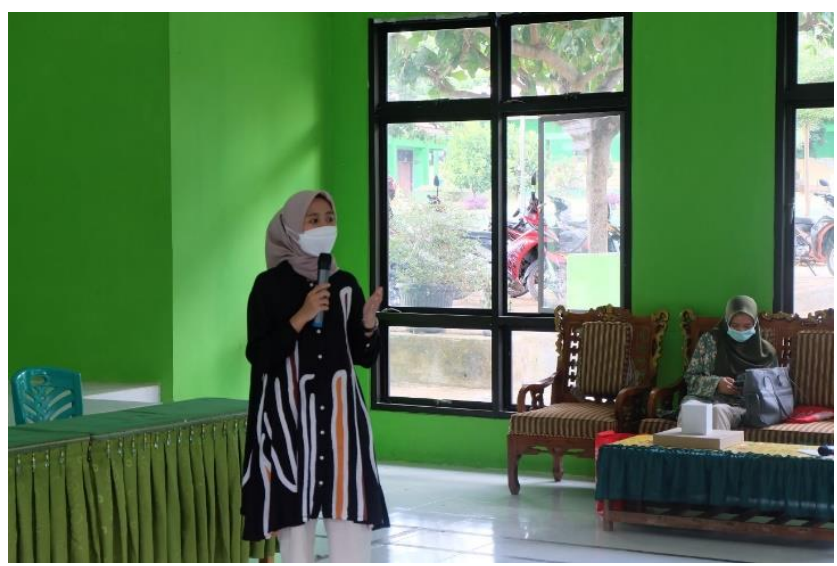




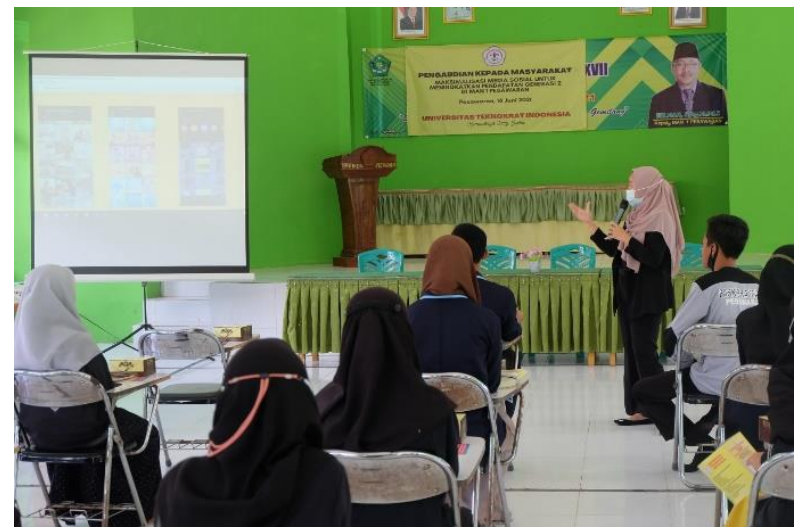

Gambar 2. Ceramah dilakukan oleh pemateri 2

2. Metode tanya jawab, dimana peserta pelatihan yaitu siswa/siswi memberikan pertanyaan seputar materi dan pemateri juga memberikan pertanyaan guna mengetahui tingkat pemahaman dan partisipasi siswa/siswi

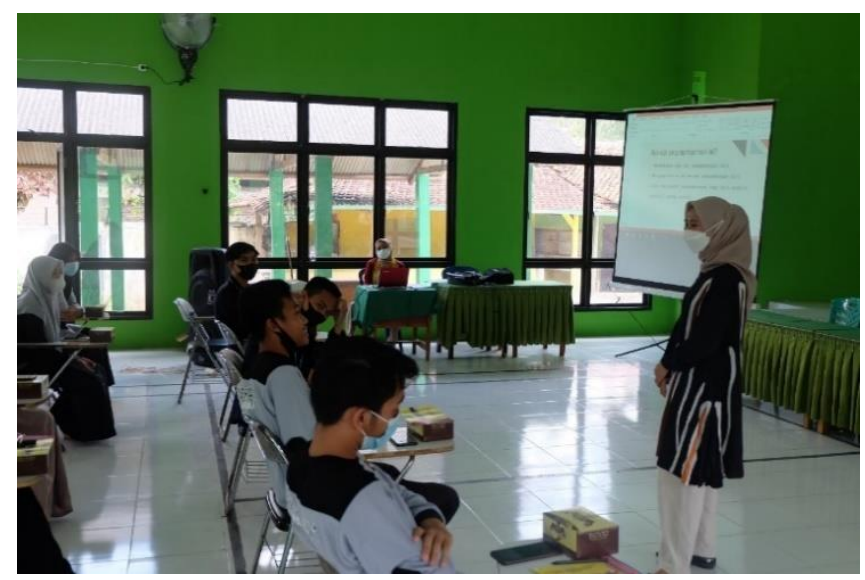

Gambar 3. Tanya Jawab siswa/siswi kepada pemateri

3. Diskusi, dimana peserta dan pemateri melakukan diskusi tentang apa saja yang telah dilakukan siswa/siswi lakukan untuk mengembangkan diri dan memanfaatkan media sosial untuk menambah pendapatan

\section{HASIL DAN PEMBAHASAN}

Kegiatan ini dilakukan di MAN 1 Pesawaran, pada tanggal 16 Juni 2021 pada 35 siswa/siswi dari kelas 1012. Kegiatan ini berlangsung sangat kondusif dan target peserta juga sudah sangat tepat dimana siswa/siswi adalah generasi $Z$ yang rata-rata sudah mengetahui berbagai aplikasi media sosial seperti Facebook, Instagram dan Tiktok. Sebelum membagikan materi, siswa/siswi diberikan pre-test agar dapat diukur sejauh mana pemahaman tentang media sosial, setelah dilakukan sosialisasi dan pemaparan materi, para siswa/siswi juga diberikan post-test untuk menganalisis sejauh mana perbedaan sebelum dan setelah diberikan materi. Pemaparan materi dibagi menjadi dua, yang pertama adalah pengembangan diri melalui pemanfaatan media sosial dan yang kedua mengenai media sosial untuk mendapatkan pendapatan. 
Kegiatan pertama ini berisi tentang salah satu bentuk pengembangan diri yang didapatkan melalui pemanfaatan media sosial. Pengembangan diri (Personal Growth) adalah hasil dari motivasi untuk memenuhi tujuan intrinsik yang ditambahkan dengan integrasi pembelajaran melalui kesadaran akan keterbatasan dan potensi pribadi (Ugur et al, 2015). Adanya kesadaran dari dalam diri siswa-siswi di bangku SMA untuk mengembangkan dirinya akan berpeluang untuk menambahkan hal-hal positif ke dalam dirinya seperti mampu memberikan rasa percaya diri yang besar, mampu menjadikan seseorang lebih proaktif dan bertanggung jawab sehingga dapat menjadi produktif, dan mampu meningkatkan kemampuan komunikasi.

Berdasarkan hasil kegiatan pertama, banyak para siswa yang telah melakukan pengembangan diri dengan mengikuti banyak kegiatan ekstrakulikuler, seminar, perlombaan, dan lain-lain. Namun, bentuk pengembangan positif tersebut tidak banyak diketahui oleh teman-teman lainnya. Hal tersebut terjadi karena siswa tidak pernah menceritakan kegiatannya ataupun menunjukkan hasil dari kegiatannya di depan teman-temannya. Oleh karena itu, adanya media sosial diperlukan untuk menunjukkan pengembangan tersebut sekaligus mengajak teman-teman lainnya untuk berkembang bersama-sama.

Para siswa di MAN 1 Pesawaran diberikan pembelajaran mengenai cara untuk menggunakan media sosialnya secara bijak dengan tujuan utama untuk mengembangkan dirinya ke tingkat yang lebih tinggi. Salah satu cara yang harus dilakukan oleh siswa adalah dengan melakukan Personal Branding atau yang dikenal dengan "merek diri". Siswa perlu mengetahui potensi dirinya terlebih dahulu dimana potensi tersebut harus dapat dijadikan sebagai identitas diri yang menjadi pembeda antara dirinya dengan teman-temannya. Seperti yang ditemui di lapangan, ada beberapa siswa yang aktif pada berbagai ekstrakulikuler seperti aktif sebagai anggota Karate, Pramuka, PMR, dan tertarik pada pembuatan desain abstrak. Potensi-potensi tersebut yang selanjutnya diarahkan kepada mahasiswa untuk dituangkan ke dalam media sosial.

Penggunaan media sosial yang tepat untuk menunjukkan potensi siswa adalah dengan membuat konten di media sosial seperti Instagram, Facebook, dan lainnya. Siswa dapat menunjukkan hobi atau ketertarikannya pada suatu hal seperti apabila ia menyukai karate, ia dapat membuat konten pada saat ia berlatih atau mengikuti kejuaraan-kejuaraan. Hal yang diharapkan dari penggunaan media sosial adalah banyak orang-orang akan mengenal siswa tersebut dengan ciri khas dan berbeda. Hal ini akan menguntungkan para siswa untuk memiliki jumlah pengikut pada media sosial yang luas, tidak hanya berasal dari sekolah yang sama bahkan bisa membangun network dari berbagai daerah, kota, bahkan negara. Setelah proses ini dijalani tentunya hal ini diharapkan akan berpotensi untuk dijadikan peluang bisnis ataupun peluang-peluang positif lainnya di media sosial.

Kegiatan kedua, pemahaman tentang media sosial untuk mendapatkan pendapatan. Pengetahuan yang pertama tentang pengaruh positif media sosial salah satunya adanya fenomena dimana individu terkenal di kalangan pengikutnya lewat profil Instagram yang disebut juga dengan microcelebrities (Djafarova \& Trofimenko, 2019). Sebagian besar dari microcelebrities' adalah konsumen aktual yang bersedia untuk mempromosikan produk yang telah mereka alami kepada konsumen potensial atau pengikutnya. Hal ini mendorong perusahaan ingin memasukkan influencer ini dalam strategi pemasaran (Park dan Lin, 2020).

Hal ini tentu dimanfaatkan perusahaan untuk mempromosikan produknya serta microcelebrities' mendapat pendapatan dari perusahaan tersebut. Menjadi microcelebrities/ influencer tentusaja membutuhkan berbagai keahlian diantaranya adalah memiliki daya tarik, dapat dipercaya, kompeten dan memiliki persentasi diri (Djafarova \& Trofimenko, 2019). Hal ini dapat menjadi peluang untuk generasi Z memperoleh mendapatan tambahan. Bukan hanya itu, sosialisasi ini juga memberikan pemahaman bahwa media sosial juga menghasilkan pekerjaan-pekerjaan baru seperti social media manager, content writter, bloger, menjadi reseller, dropshiper bahkan mengelola bisnis sendiri dengan memanfaatkan fitur-fitur yang ada di Instagram dan Facebook. Selanjutnya pemahaman tentang pengaruh negatif media sosial juga didiskusikan dalam kegiatan ini.

Berdasarkan angket yang disebarkan kepada siswa/siswa MAN 1 Pesawaran terdapat perbedaan pemahaman setelah dan sebelum dilakukan sosialisasi. Pada saat sebelum dilakukan sosialisasi, ada pre-test yang berisikan lima pertanyaan mengenai pengetahuan siswa terkait pemanfaatan media sosial. Dari 35 siswa yang mengisi kuisioner dapat diketahui bahwa banyak siswa yang masih belum memiliki pengetahuan mengenai pemanfaatan media sosial. Selanjutnya, siswa-siswi juga banyak yang belum memahami fitur-fitur bisnis di media sosial terlebih fitur-fitur yang memiliki fungsi untuk mendapatkan pendapatan tambahan seperti fitur target konsumen. Selain itu, ada keraguan di dalam jawaban mengenai tingkat pemahaman mereka terkait media sosial dan pengaruh dari pemahaman media sosial yang dapat membantu UMKM sekitar. Adanya keraguan tersebut menunjukkan bahwa para siswa masih belum memahami penggunaan media sosial yang dapat menghasilkan pendapatan. Para siswa berharap dari adanya pelatihan mengenai pemahaman media sosial dapat membantu mereka untuk menambah pendapatan. 
Setelah adanya pelatihan, post test diberikan kembali kepada para siswa-siswi MAN 1 Pesawaran. Kuisioner berisikan lima pertanyaan yang sama dengan kuisioner yang dibagikan pada saat pre-test. Berdasarkan hasil kuisioner yang diisi oleh para siswa, diketahui bahwa mayoritas siswa menjawab setuju untuk kelima pertanyaan yang diberikan. Dari adanya pelatihan telah menambah pengetahuan mengenai pemanfaatan media sosial. Siswa juga mulai memahami fitur-fitur dasar di media sosial dan memiliki dorongan untuk yakin apabila mereka telah memahami media sosial dengan baik, maka mereka dapat menambah pendapatan bagi diri sendiri dan dapat membantu UMKM sekitar.

\section{KESIMPULAN}

Berdasarkan hasil pelatihan dan sosialisasi, siswa/siswi telah memahami manfaat media sosial dengan sangat baik yang dimulai dengan melakukan pengembangan diri seperti melakukan personal branding pada akun media sosial yang dimiliki. Oleh karena itu, hal ini diharapkan dapat menjadi bekal siswa/siswi untuk mencari pekerjaan ataupun melakukan bisnis dan memahami dampak negatif media sosial. Selanjutnya pelatihan ini juga memberikan wawasan bahwa banyak berbagai pekerjaan baru yang hadir seiring dengan kemunculan media sosial sehingga mereka dapat maksimal memanfaatkan media sosial. Berbagai siswa/siswi juga telah memiliki bisnis online, sehingga pelatihan selanjutnya dapat dilakukan untuk fokus membahas lebih spesifik tentang fitur media sosial untuk bisnis.

\section{UCAPAN TERIMA KASIH}

Terima kasih kepada Yayasan Universitas Teknokrat Indonesia yang telah memberikan pendanaan pada kegiatan Pengabdian Masyarakat, sehingga kegiatan ini dapat berjalan dengan baik..

\section{REFERENSI/DAFTAR PUSTAKA}

Djafarova, E., \& Trofimenko, O. (2018). Instafamous - credibility and self-presentation of micro-celebrities on social media. Information, Communication \& Society, 1-16.

Felix, R., Rauschnabel, P. A., \& Hinsch, C. (2017). Elements of strategic social media marketing: A holistic framework. Science Direct, 118-126.

Kominfo. (2017, June $\quad 3)$ kominfo.go.id. $\quad$ Retrieved from https://www.kominfo.go.id/content/detail/8637/pemerintah-ingin-media-sosial-dimanfaatkan-untuk-halproduktif/0/sorotan_media

Ugur, H., Constantinescu, P.-M., \& Stevens, M. J. (2015). Self-Awareness and Personal Growth: Theory and Application of Bloom's Taxonomy. Eurasian Journal of Educational Research, 1-22. 


\section{BIOGRAFI PENULIS}

\begin{tabular}{|l|l|}
\hline Penulis Pertama & Lia Febria Lina \\
\hline Penulis Kedua & Almira Devita Putri \\
\hline & \\
\hline
\end{tabular}

